\title{
Toxicity of pymetrozine and thiamethoxam to Aphelinus gossypii and Delphastus pusillus ${ }^{(1)}$
}

\author{
Jorge Braz Torres ${ }^{(2)}$, Christian Sherley Araujo Silva-Torres ${ }^{(2)}$ and José Vargas de Oliveira(2)
}

\begin{abstract}
The objective of this work was to study the toxicity of pymetrozine and thiamethoxam to the cotton aphid parasitoid Aphelinus gossypii Timberlake and to the whitefly predator Delphastus pusillus (LeConte). Cotton leaves containing mummies of the parasitoid A. gossypii were collected and treated with seven concentrations of both insecticides. Parasitoid emergence was not affected by pymetrozine and ranged from $59.9 \%$ to $75.0 \%$, but decreased with the increase of thiamethoxam concentrations ranging from $30.2 \%$ to $69.6 \%$. Cotton leaves infested by whitefly and treated with recommended rates of both insecticides were collected three hours, three days and six days after spraying and colonized with larvae and adults of $D$. pusillus. Predators released on thiamethoxamtreated leaves experienced mortality from $70 \%$ to $100 \%$, while those released on pymetrozine-treated leaves showed mortality from $0 \%$ to $20 \%$. Topical toxicity from both insecticides was studied on larvae, pupae and adults of $D$. pusillus. The survival of predator after six days of exposure to 400,600 and $800 \mathrm{mg} / \mathrm{L}$ of pymetrozine a.i. was higher than $69.6 \%$, and to 25,100 and $200 \mathrm{mg} / \mathrm{L}$ of thiamethoxam a.i. was lower than $8.7 \%$. The toxicity data for $A$. gossypii and D. pusillus characterize the pymetrozine as harmless for both species, and thiamethoxam of low to moderate toxicity for A. gossypii treated mummies, and high toxicity for $D$. pusillus.
\end{abstract}

Index terms: Gossypium, infestation, parasitoids, insecticide selectivity.

Toxicidade de pimetrozine e tiametoxam a Aphelinus gossypii e Delphastus pusillus

Resumo - O objetivo deste trabalho foi estudar a toxicidade de pimetrozine e tiametoxam ao parasitóide do pulgão-do-algodoeiro Aphelinus gossypii Timberlake e ao predador da mosca-branca Delphastus pusillus (LeConte). Folhas de algodoeiro contendo múmias do parasitóide $A$. gossypii foram coletadas e tratadas com sete concentrações de ambos inseticidas. A emergência do parasitóide não foi afetada pelo pimetrozine e variou de $59,9 \%$ a $75 \%$, enquanto as múmias tratadas com tiametoxam produziram emergência de A. gossypii variando de $30,2 \%$ a 69,6\%. Plantas infestadas por mosca-branca e tratadas com três concentrações recomendadas de ambos inseticidas foram coletadas três horas, três dias e seis dias após tratamento e colonizadas com larvas e adultos de D. pusillus. Os predadores liberados em folhas tratadas com tiametoxam apresentaram mortalidades de $70 \%$ a $100 \%$, enquanto aqueles liberados em folhas tratadas com pimetrozine apresentaram mortalidade de $0 \%$ a $20 \%$. Seis dias após tratamento tópico de larvas, pupas e adultos de D. pusillus com pimetrozine (i.a.) a 400, 600 e $800 \mathrm{mg} / \mathrm{L}$, a população viva era acima de $69,6 \%$, enquanto os tratados com tiametoxam (i.a.) a 25, 100 e $200 \mathrm{mg} / \mathrm{L}$, apresentaram sobrevivência abaixo de $8,7 \%$. O pimetrozine foi inócuo para $A$. gossypii e $D$. pusillus, e o tiametoxam mostrou toxicidade de baixa a moderada para múmias de $A$. gossypii e foi altamente tóxico a D. pusillus.

Termos para indexação: Gossypium, infestação, parasitóide, seletividade de inseticidas.

\footnotetext{
(1) Accepted for publication on January 8, 2003.

Partially supported by Universidade Federal Rural de Pernambuco (UFRPE) and SEAG2002 (Syngenta Entomological Advisory Group).

(2) UFRPE, Dep. de Agronomia e Fitossanidade, Av.Dom Manoel de Medeiros, s/n, Dois Irmãos, CEP 52171-900 Recife, PE. E-mail: jtorres@bugs.ent.uga.edu, sherleyj@uga.edu, vargasoliveira@uol.com.br
}

\section{Introduction}

The tobacco whitefly Bemisia tabaci (Genn.) (Homoptera: Aleyrodidae) and the cotton aphid Aphis gossypii Glover (Homoptera: Aphididae) are widely spread throughout the tropics and subtropics, damaging many crops including cotton. Although 
these species were recognized as cotton pests for a long time, just recently their status changed from occasional to frequent outbreak pests, probably due to changes on cotton production systems such as improved varieties with emphasis on yield, $\mathrm{N}$ fertilization, resistance to insecticides, among others (Ernst, 1996; Elbert \& Nauen, 2000; Godfrey et al., 2000; Jauset et al., 2000). These species cause indirect and direct injuries by virus transmission and, depending on the duration of the infestation and insect population levels, cotton yield can be seriously endangered (Slosser et al., 2001). In addition, both species secrete honeydew on leaves and on open lint. This favors the development of black sooty mould fungi, which affects plant physiology and result in sticky lint with severe problems during the spinning process at textile mills.

Chemical control has been intensively used against tobacco whitefly and cotton aphid, which may disrupt the natural control provided by parasitoids and predators of these and other pests present in cotton ecosystems. Preventing insect vectors of plant diseases is usually a more effective strategy than remedial treatments adopted by field and greenhouse growers (Mason et al., 2000) and the use of preventive insecticides in cotton has been questioned in relation to the effects on natural enemies (Turnipseed \& Sullivan, 1999; Hagerty et al., 2000). Thus, a way to prevent insect damage is judiciously using insecticides in an integrated pest management program, preferring compounds with minimum effects on natural enemies.

Pymetrozine, a pyridine azomethine compound, is a novel insecticide with selective activity against homopteran insects like the cotton aphid and the tobacco whitefly in cotton (Nicholson et al., 1995; Lawson et al., 1999). Pymetrozine acts in a unique way interfering in the nervous regulation of feeding behavior, which consequently results in death due to starvation after a few days (Nicholson et al., 1995). Besides the efficacy, pymetrozine has shown selectivity in favor of the parasitoids Aphelinus abdominalis Dalman and Encarsia formosa Gahan in greenhouse treatments for controlling aphids and whiteflies (Sechser et al., 1994). Thiamethoxam is a second-generation neonicotinoid compound with stomach and contact activity. It belongs to the sub- class thianicotinyl of the neonicotinoid insecticides, which interferes with the nicotinic acetylcholine receptors in the insect nervous system (Maiensfisch et al., 2001). After foliar, soil application or as seed treatment, it has systemic and long residual activity in several plants for a broad range of commercially important sucking pests and some coleopteran and lepidopteran pests as well. Due to its broad spectrum for insect control and variety of formulations (Actara 25 WG, 1 GR, 240 SC; and Cruiser 350 FS, $70 \mathrm{WS}$ ), thiamethoxam recommendations will be soon extended to many pests and crops where whiteflies and aphids occur as pest. On the other side, the aphelinid parasitoid Aphelinus gossypii Timberlake (Hymenoptera: Aphelinidae) and the coccinellid predator Delphastus pusillus (LeConte) (Coleoptera: Coccinellidae) are important natural enemies of cotton aphid and whiteflies, respectively, which have been receiving attention not only in cotton but also in other ecosystems as regulatory agents of pest species (Hoelmer et al., 1993; Heinz et al., 1994; Tokumaru \& Takata, 1996; Fernandes et al., 2000; Godfrey et al., 2000).

The objective of this work was to study the toxicity of pymetrozine and thiamethoxam to the cotton aphid parasitoid Aphelinus gossypii Timberlake and on the whitefly predator Delphastus pusillus (LeConte).

\section{Material and Methods}

This work was carried out at the Laboratório de Controle Biológico of the Universidade Federal Rural de Pernambuco (UFRPE), Recife, PE, Brazil. The insecticides pymetrozine (Chess $25 \mathrm{WP}$ ) and thiamethoxam (Actara $250 \mathrm{WP}$ ) were provided by Syngenta of Brazil (São Paulo, Brazil). The effects of the insecticides pymetrozine and thiamethoxam on cotton aphid parasitoid Aphelinus gossypii mummies were investigated using seven concentrations from the lowest to the highest recommended concentrations for different crops and pests (pymetrozine (a.i.): 0, 75, 150, 250, 350, 450, 550 and $650 \mathrm{mg} / \mathrm{L}$; thiamethoxam (a.i.): 0, 3.9, $7.8,15.6,31.25,62.5,125$, and $250 \mathrm{mg} / \mathrm{L}$ ).

The parasitoid A. gossypii tested was reared on cotton aphid Aphis gossypii Glover (Homoptera: Aphididae) colonies on cotton plants CNPA Precoce 1, and the predatory coccinellid Delphastus pusillus was maintained on kale plants (Brassica oleraceae L. cultivar Manteiga) infested by the whitefly Bemisia tabaci. Both colonies were main- 
tained on plants cultivated in jars and open-sided greenhouse, under natural conditions, and without previous contact with insecticides.

The treatments consisted of cotton leaves containing aphids and at least 30 mummies parasitized by $A$. gossypii. For each treatment (two insecticides and seven concentrations each) three cotton leaves (replications) were collected and treated using a DeVilbs sprayer calibrated at $1 \mathrm{~mL} / \mathrm{leaf}$ for each insecticide and concentration. Black mummies without parasitoid emergence (dorsal holes) were dislodged from leaves under light microscope, three hours after treatment using a camel hairbrush. They were individualized (i.e., early parasitism) as well as mummies formed up to day 4 after treatment (i.e., late parasitism). The mummies were maintained inside vials $(6 \mathrm{~cm} \mathrm{x}$ $\varnothing 1.5 \mathrm{~cm})$ at controlled conditions $\left(27 \pm 2^{\circ} \mathrm{C}, 60-75 \% \mathrm{RH}\right)$ Parasitoid emergence and emergence date were daily recorded. Longevity of adults emerged from early parasitism deprived of food and host was studied. Ten to fifteen adults from the second day of emergence per insecticide concentration and treatment control were placed into other vials at the rate of five parasitoids per vial, and recorded the mortality daily.

Topical and residual effects of the insecticides pymetrozine (a.i.) at concentrations $0,400,600$ and $800 \mathrm{mg} / \mathrm{L}$, and thiamethoxam (a.i.) at concentrations $0,25,100$ and $200 \mathrm{mg} / \mathrm{L}$, on the whitefly predator $D$. pusillus larvae, pupae and adults were studied. Topical exposure treatments consisted of cotton leaves infested by nymphs and pupae of tobacco whitefly, and ten larvae (4th/5th instars), ten pupae and 20 adults of the predator per replicate and insecticide concentration caged in plastic cages. Treated and untreated cotton leaves and predators were confined in a plastic cylindrical cage $(15 \mathrm{~cm}$ diameter, and $20 \mathrm{~cm}$ height) containing four holes closed with organdie fabric for ventilation, and cultured in controlled conditions of $27 \pm 2^{\circ} \mathrm{C}$ and $65 \pm 10 \% \mathrm{RH}$. A total of eight treatments (two insecticides and four concentrations each insecticide) were composed with three replications (cages) each. Cotton leaves containing pest and predator were sprayed using a DeVilbs sprayer calibrated at $1 \mathrm{~mL} / \mathrm{leaf}$ for each insecticide and concentration. The number of live adults was scored and removed four, five, and six days after spraying and the percentage of survival were averaged after six days. Residual effects were studied confining 20 larvae and 20 adults of the predator on treated cotton leaves 3 hours (day 0), 3 and 6 days post-spraying. Cotton leaves were collected from treated plants grown under open-sided greenhouse conditions at each interval after spraying. The leaves were placed with the petiole through a hole in the plastic lids of vials containing water. Due to mortality of prey, at the intervals of three and six days after spraying, a $4 \mathrm{~cm}^{2}$ of untreated kale leaves containing whitefly nymphs and pupae (more than 30 nymphs and pupae/ $\mathrm{cm}^{2}$ ) were placed over the treated cotton leaves to provide food to the predators. Mortalities were scored after 24 hours. Mortalities from topical treatment were corrected by natural mortality of control treatments Abbott (1925). Parasitoid emergence, developmental time and adult longevity were subjected to regression analysis with insecticide concentrations as independent variable. All analyses were performed using the proc GLM of the statistical package SigmaStat 2.03 (Statistical..., 1997). The mortality of $D$. pussilus treated topically with both insecticides was used to classify the insecticides toxicity according to categories developed by the IOBC Working Group "Pesticides and Beneficial Organisms" as harmless (mortality $<30 \%$ ), slightly harmful (mortality: 30\%-80\%), moderately harmful (mortality: 80\%-99\%) and harmful (mortality $>99 \%$ ) (Hassan, 1992).

\section{Results and Discussion}

The insecticides thiamethoxam and pymetrozine differ in their effects on A. gossypii emergence according to the concentration tested, but not on parasitoid developmental times and longevity. Thiamethoxam significantly reduced $A$. gossypii emergence ranging from $30.2 \%$ to $69.6 \%$ by increasing concentrations, while pymetrozine showed similar emergence at all studied concentrations (Figure 1). However, parasitoid emergence from late parasitism (i.e., mummies formed up to four days after spraying) was not affected by both insecticide treatments (pymetrozine, 64.6 $\pm 2.46 \%$; df $=1,16, \mathrm{~F}=1.94$, $\mathrm{p}=0.167$; and thiamethoxam, $66.9 \pm 2.42 \% ; \mathrm{df}=1,18$, $\mathrm{F}=2.17, \mathrm{p}=0.109)$. Thus, no direct effects were observed on emergence of parasitoids treated at stages prior to pupa formation. However, indirect effects may be expected when host mortality takes place before the parasitoid larva develops. The development of A. gossypii from egg to emergence is about 15 days at $27^{\circ} \mathrm{C}$, and development of mummies was observed from 7 to 11 days after oviposition (Tokumaru \& Takata, 1996). This fact suggests that parasitoid time to emerge from pupal stages (less than 4.5 days, Figure 1) was not affected by any of the insecticides, nor was the emergence from mummies formed up to day 4 after treatment. 
The cotton aphid parasitoid A. gossypii was able to develop and emerge under these insecticide treatments. After four days post-treatment, no more mummy formation and live aphids were observed. Indeed, one day post-treatment with thiamethoxam all aphids were dead and found at the bottom of the cages. Aphids stayed alive for two or three days under pymetrozine treatments. Thiamethoxam treatment is expected to have quick action while pimetrozine curtails feeding activities during this period (Nicholson et al., 1995; Maiensfisch et al., 1999). However, this distinct action did not have apparent effects on parasitoid emergence treated prior to the mummy stages, although the numbers of mummies harvested under pymetrozine treatment ( $\mathrm{n}=169$ mummies) were almost twice those harvested under thiamethoxam treatments ( $\mathrm{n}=91$ mummies). The results achieved with pymetrozine agree with those reported by Sechser et al. (1994) for
A. abdominalis and E. formosa, as well as with neonicotinoids on aphid parasitoids at mummy stages in protected crops (Ogata, 1999). On the other side, Bradley et al. (1997) reported $81 \%$ mortality for Aphelinus mali (Hald) adults exposed to dry residues of the neonicotinoid imidacloprid. These results suggest that effects of insecticide treatments on parasitoid mummies are minimized compared to topical contact. Therefore, topical and residual effects of pymetrozine and thiamethoxam on adult parasitoids should be studied.

The longevity of adults emerged from treated and untreated mummies did not differ (thiamethoxam, $\mathrm{df}=1,29, \mathrm{~F}=0.19, \mathrm{p}=0.666, \mathrm{n}=155$ adults; and pymetrozine, $\mathrm{df}=1,34, \mathrm{~F}=1.73, \mathrm{p}=0.196$, $\mathrm{n}=181$ adults) and ranged from 1 to 2.8 days for both insecticides at studied conditions. The conditions of food and host deprivation induced short parasitoid longevity. Tokumaru \& Takata (1996) found that
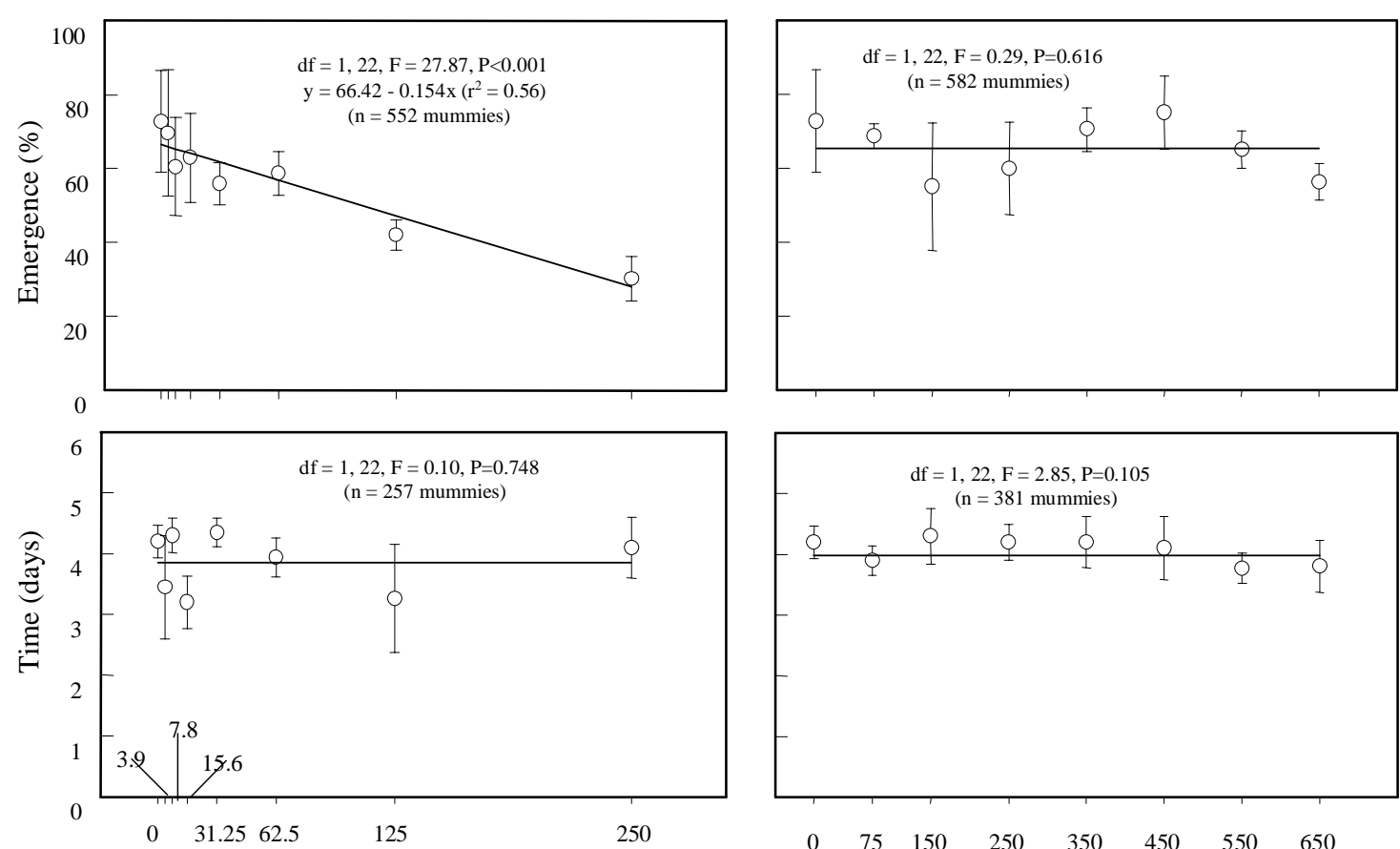

Thiamethoxam concentration $(\mathrm{mg} / \mathrm{L})$

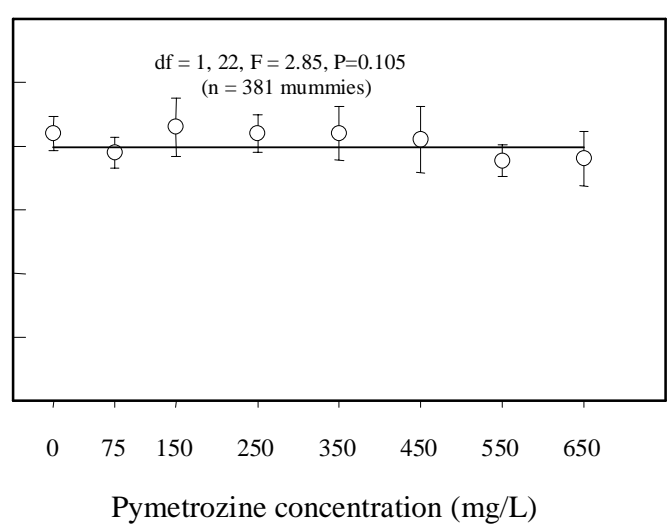

Figure 1. Emergence and time spent from insecticide application to emergence (days) of Aphelinus gossypii (Hymenoptera: Aphelinidae) from Aphis gossypii (Homoptera: Aphididae) mummies treated with different thiamethoxam and pymetrozine concentrations. Recife, PE, 2000. Bars in each point represents mean \pm standard error. 
A. gossypii lives from 5 to 13 days having hosts available and resulted in one host killed by feeding for 5.3 eggs deposited.

The coccinellid predator $D$. pusillus is a specialist on whitefly species with potential for biological control programs (Hoelmer et al., 1993; Heinz et al., 1994). However, D. pusillus larvae have low mobility on the plant and concentrate on whitefly colonies. Therefore, they may be greatly affected by insecticide applications. The percentages of adults yielded from topical treatment after six days when no more larvae and pupal stages were observed inside cages from leaves infested with ten larvae, ten pupae and 20 adults of the predator and sprayed with pymetrozine at $0,400,600$ and $800 \mathrm{mg} / \mathrm{L}$ were $100 \%$, $77 \%, 100 \%$ and $69.6 \%$ (Figure 2); the insecticide toxicity fitted within the categories of harmless to slightly harmful according to the IOBC methods (Hassan, 1992). On the other side, predators topically treated with thiamethoxam at $0,25,100$ and $200 \mathrm{mg} / \mathrm{L}$ produced $97.4 \%, 2.7 \%, 8.7 \%$ and $8.3 \%$ of live adults after six days from treatment and the insecticide toxicity was included in the categories of moderately harmful to harmful (Figure 2).

The insecticide pymetrozine through residual treatment showed lower (less than 20\%) or no mor-

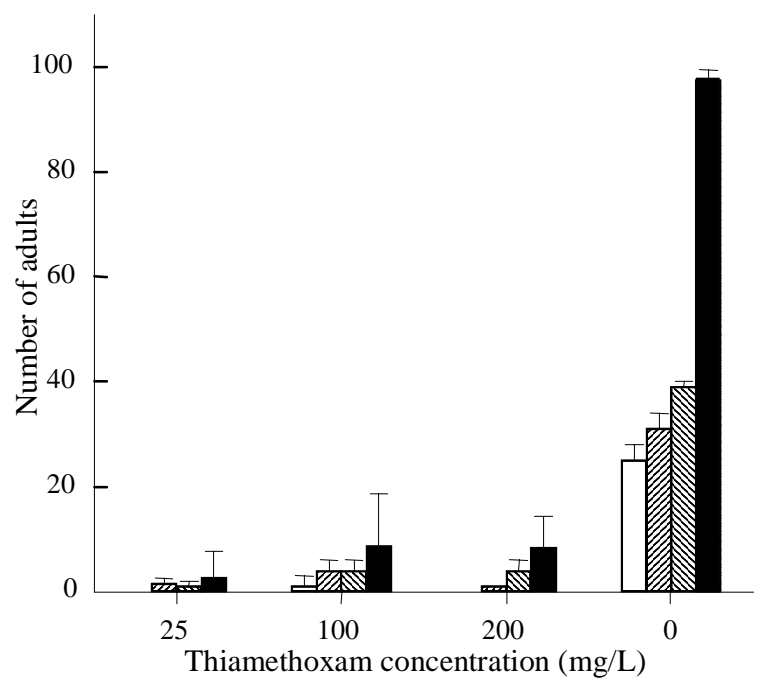

tality at 0,3 and 6 days after larvae and adults exposure fitting to the categories of harmless insecticide to $D$. pusillus. The thiamethoxam showed mortality rate within $30 \%$ to $80 \%$ and over $80 \%$ for larvae and adults fitting to the moderately harmful to harmful insecticide to D. pusillus (Figure 3). These results resemble those by Torres et al. (2002) when evaluating the interaction of insecticides and the predatory stinkbug Podisus nigrispinus (Dallas) in cotton, in which pymetrozine caused no effect on the predator survival and predation rate, while the thiamethoxam caused $100 \%$ mortality of the caged predators on treated plants up to 72 hours after exposure.

Recently, attention has been addressed to multiple control methods emphasizing natural control more than ever before. Preventing or reducing pest outbreaks by promoting natural control, reducing spray frequency and, hence, increasing insecticide lifetime is a general consensus. Thus, chemical companies in developing and marketing their insecticides have considered toxicity on natural enemies as an important variable. This strategy appears credible in general, but regarding a multispecies pest ecosystem such as cotton, the natural enemy conservation is a challenge.

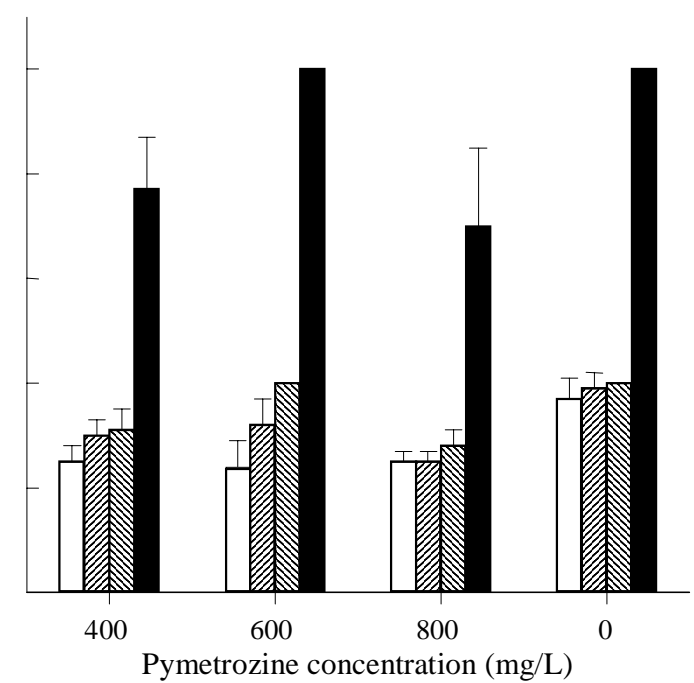

Figure 2. Adults (number) of Delphastus pusillus (Coleoptera: Coccinellidae) yielded from larvae, pupae and adults untreated and topical treated four $(\square)$, five $(\mathbb{U} \mathbb{G})$, and six $(\mathbb{Q})$ days post-treatment with three concentrations of thiamethoxam and pymetrozine and mean $(\square$ ) survival at day 6. Recife, PE, 2000. Bars in each column represents mean \pm standard error. 

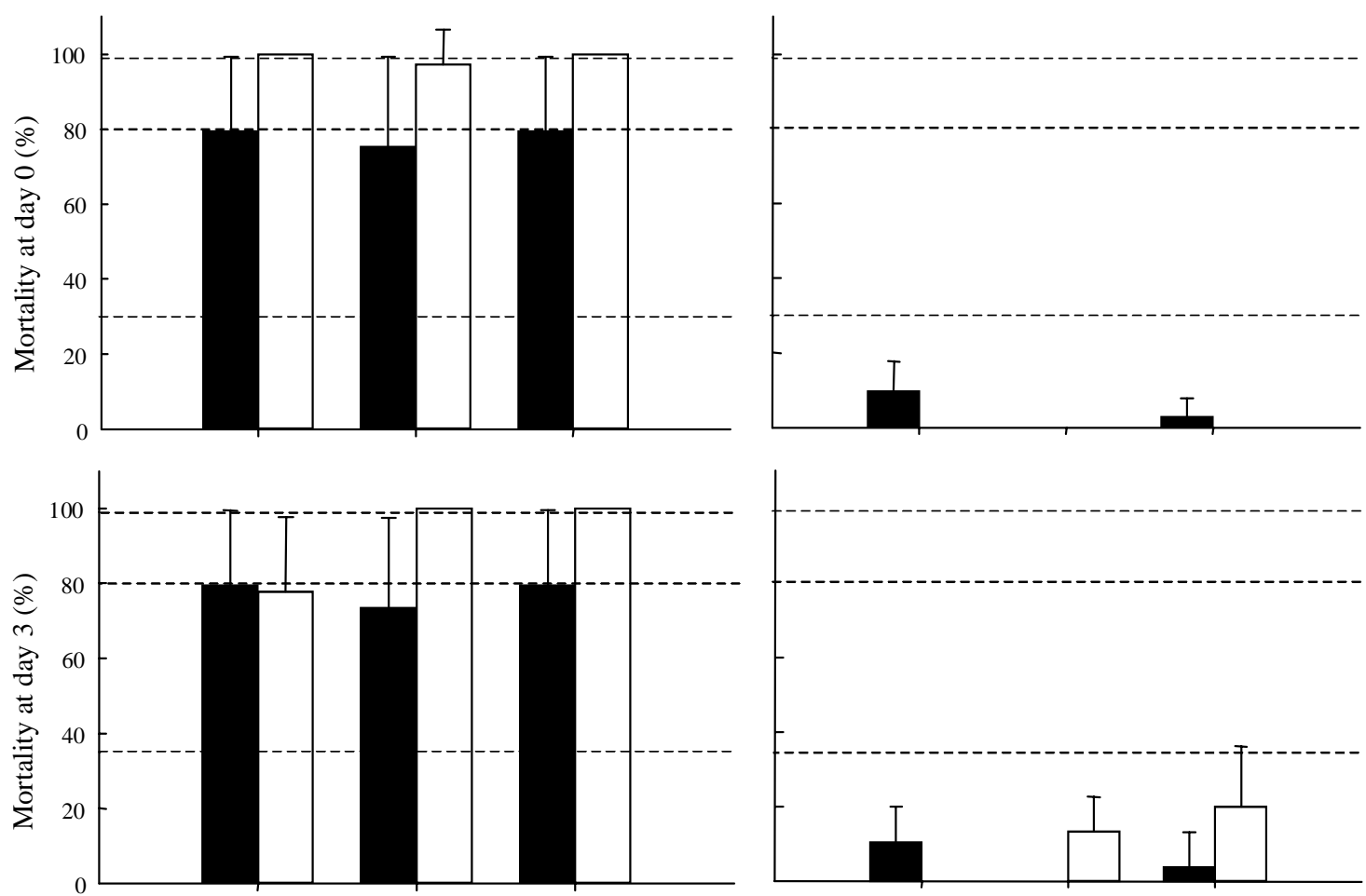

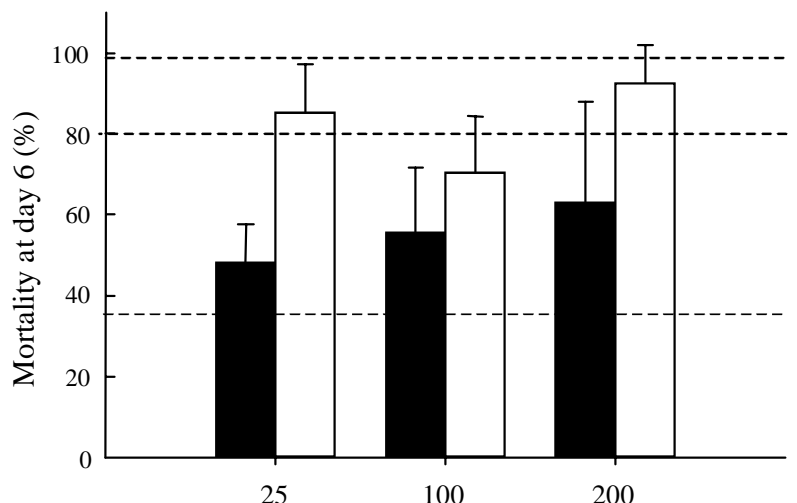

Thiamethoxam concentration $(\mathrm{mg} / \mathrm{L})$

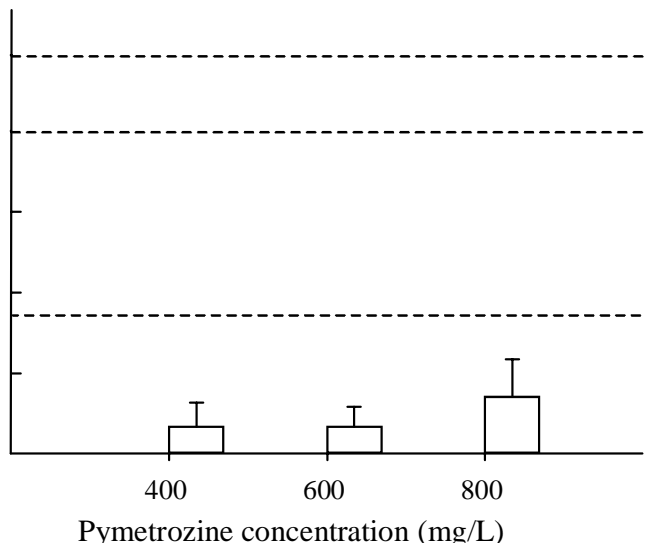

Pymetrozine concentration $(\mathrm{mg} / \mathrm{L})$

Figure 3. Residual toxicity of thiamethoxam and pymetrozine to larvae $(\square)$ and adults (

of Delphastus pusillus (Coleoptera: Coccinellidae) confined on cotton leaves treated with different insecticide concentrations at spraying time (day 0), 3 and 6 days after application. Dotted lines indicate 30\%, 80\% and 99\% mortality. Recife, PE, 2000. Bars in each column represents mean \pm standard error.

Based on toxicity rate for mummies of A. gossypii (Figure 1) and D. pusillus (Figures 2 and 3), the insecticide pymetrozine proved to be harmless for both, while thiamethoxam showed low to moderate toxicity for A. gossypii treated mummies and it was highly toxic for D. pusillus at all tested concentrations and time after application, which should be considered when preserving these natural enemies in cotton ecosystem. The availability of thiamethoxam formulations to use through seed treatment and drench, 
which prevents exposure of parasitoids and chewing predators inside plants from insecticides, should be considered.

\section{Conclusions}

1. The insecticide pymetrozine does not affect Aphelinus gossypii nor the whitefly predator Delphastus pusillus.

2. The insecticide thiamethoxam shows low to moderate toxicity to Aphelinus gossypii based on its decrease emergence by increasing insecticides concentrations; in contrast, thiamethoxam is highly toxic for larvae, pupae and adults of whitefly predator Delphastus pusillus.

\section{Acknowledgements}

To Mark Dalusk (Department of Entomology, University of Georgia), for his comments on the draft of this manuscript; to Dr. Paulo Aramaki (Syngenta of Brazil), for providing the insecticides; to Dr. M.A. Schauff (USDA-ARS, Beltsville, MD), for determining specimens of Aphelinus gossypii; to Dr. R.D. Gordon (USDA-ARS, Washington, DC), for determining specimens of Delphastus pusillus; to Dra. M.R. Vilarinhos (Embrapa-Centro Nacional de Pesquisa de Recursos Genéticos e Biotecnologia, DF, Brazil), for certifying the whitefly colony identification.

\section{References}

ABBOTT, W. S. A method of computing the effectiveness of an insecticide. Journal of Economic Entomology, Lanham, v. 8, n. 1, p. 265-267, Jan. 1925.

BRADLEY, S. J.; MURRELL, V. C.; SHAW, P. W.; WALKER, J. T. S. Effect of orchard pesticides on Aphelinus mali, the woolly apple aphid parasitoid. In: NEW ZEALAND PLANT PROTECTION SOCIETY CONFERENCE, 50., 1997, Lincoln. Proceedings... Lincoln: New Zealand Plant Protection Society, 1997. p. 218-223.

ELBERT, A.; NAUEN, R. Resistance of Bemisia tabaci (Homoptera: Aleyrodidae) to insecticides in southern Spain with special reference to neonicotinoids. Pest Management Science, London, v. 56, n. 1, p. 60-64, Jan. 2000.
ERNST, G. H. Whiteflies (Bemisia tabaci) in cotton: possible origin of the problem and today's chemical control opportunities. Pesticide Science, London, v. 52, n. 1, p. 139-141, Jan. 1996.

FERNANDES, A. M. V.; FARIAS, A. M. I.; FARIA, C. A.; TAVARES, M. T. Ocorrência de Aphelinus gossypii Timberlake (Hymenoptera: Aphelinidae) parasitando Aphis gossypii Glover (Hemiptera: Aphididae) em algodão no Estado de Pernambuco. Anais da Sociedade Entomológica do Brasil, Londrina, v. 29, n. 4, p. 831-834, dez. 2000.

GODFREY, L. D.; ROSENHEIM, J. A.; GOODELL, P. B. Cotton aphid emerges as major pest in SJV cotton. California Agriculture, Oakland, v. 54, n. 6, p. 26-29, Nov./Dec. 2000.

HAGERTY, A. M.; TURNIPSEED, S. G.; SULLIVAN, M. J. Impact of beneficial arthropod conservation in B. T. and conventional cotton. In: BELTWIDE COTTON CONFERENCE, 2000, Nashville. Proceedings... Memphis: National Cotton Council, 2000. v. 2, p. 976-978.

HASSAN, S. A. Guidelines for testing the effects of pesticides on beneficial organisms: description of test methods. IOBC Bulletin, Montpellier, v. 15, n. 3, p. 1-186, 1992.

HEINZ, K. M.; BRAZZLE, J. R.; PICKETT, C. H.; NATWICK, E. T.; NELSON, J. M.; PARRELLA, M. P. Predatory beetle may suppress silverleaf whitefly. California Agriculture, Oakland, v. 48, n. 2, p. 35-40, Mar./ Apr. 1994.

HOELMER, K. A.; OSBORNE, L. S.; YOKOMI, R. K. Reproduction and feeding behavior of Delphastus pusillus (Coleoptera: Coccinellidae): a predator of Bemisia tabaci (Homoptera: Aleyrodidae). Journal of Economic Entomology, Lanham, v. 86, n. 2, p. 322-329, Feb. 1993.

JAUSET, A. M.; SARASUA, M. J.; AVILLA, J.; ALBAJES, R. Effect of nitrogen fertilization level applied to tomato on the greenhouse whitefly. Crop Protection, Oxford, v. 19, n. 4, p. 255-261, May 2000.

LAWSON, D. S.; DUNBAR, D. M.; WHITE, S. M.; NGO, N. Actara ${ }^{\mathrm{TM}} 25 \mathrm{WG}$ : control of cotton pests with a new neonicotinoid insecticide, thiamethoxam. In: BELTWIDE COTTON CONFERENCE, 1999, Nashville. Proceedings... Memphis: National Cotton Conference, 1999. v. 2, p. 1106-1109.

MAIENSFICH, P.; GSELL, L.; RINDLISBACHER, A. Synthesis and insecticidal activity of CGA 293 343: a novel broad-spectrum insecticide. Pesticide Science, London, v. 55, n. 2, p. 351-355, Feb. 1999. 
MAIENSFISCH, P.; HUERLIMANN, H.; SLOSSER, J. E.; PARAJULEE, M. N.; IDO, G. B.; RINDLISBACHER, A.; GSELL, L.; DETTWILER, H.; RUMMEL, D. R. Cotton aphid response to irrigation and HAETTENSCHWILER, J.; SYEGER, E.; WALTI, M. crop chemicals. Southwestern Entomologist, Dallas, The discovery of thiamethoxam: a second-generation $\quad$ v. 26, n. 1, p. 1-14, Mar. 2001.

neonicotinoid. Pest Management Science, London, v. 57, n. 2, p. 165-176, Feb. 2001.

MASON, G.; RANCATI, M.; BOSCO, D. The effect of thiamethoxam, a second generation neonicotinoid insecticide, in preventing transmission of tomato yellow leaf curl gemminivirus (TYLCV) by whitefly Bemisia tabaci (Gennadius). Crop Protection, Oxford, v. 19, n. 7, p. 473-479, Aug. 2000.

NICHOLSON, W. F.; SENN, R.; FLUECKIGER, C. R.; FUOG, D. Pymetrozine: a novel compound for control of whiteflies. In: GERLING, D.; MAYER, D. (Ed.). Bemisia: taxonomy, biology, damage, control and management. Andover: Intercept, 1995. p. 635-639.

OGATA, Y. Integration of biological control and chemical control in case of Japan. IOBC Bulletin, Montpellier, v. 22, n. 1, p. 189-191, Sept. 1999.

SECHSER, B.; BOURGEOIS, F.; REBER, B.; WESIAK, $\mathrm{H}$. The integrated control of whiteflies and aphids on tomatoes in glasshouses with pymetrozine. Mededelingen Faculteit Landbouwkundige \& Toegepaste Wetenschappen Universiteit Gent, Gent, v. 59, n. 4, p. 579-583, Sept. 1994.

STATISTICAL PRODUCT AND SERVICE SOLUTIONS INC. (Chicago, United States). SIGMASTAT 2.03: SigmaStat Statistica software user's manual. Chicago, 1997. 1989 p.

TOKUMARU, S.; TAKATA, H. Numbers of eggs deposited and host feeding in Aphelinus gossypii Timberlake (Hymenoptera: Aphelinidae), a parasitoid of Aphis gossypii Glover (Homoptera: Aphididae). Japan Journal of Applied Entomology and Zoology, Tokyo, v. 40, n. 1, p. 242-244, Feb. 1996.

TORRES, J. B.; SILVA-TORRES, C. S. A.; OLIVEIRA, M. R.; FERREIRA, J. Compatibilidade de inseticidas e acaricidas com o percevejo predador Podisus nigrispinus (Dallas) (Heteroptera: Pentatomidae) em algodoeiro. Neotropical Entomology, Londrina, v. 31, n. 2, p. 311-317, ago. 2002.

TURNIPSEED, S. G.; SULLIVAN, M. J. Consequences of natural enemy disruption with applications of "hard" insecticides in conventional and B. T. cotton. In: BELTWIDE COTTON CONFERENCE, 1999, Nashville. Proceedings... Memphis: National Cotton Council, 1999. v. 2, p. 1110-1112. 